\title{
Implementasi Electronic Nose dan Support Vector Machine pada Aplikasi Olfactory Mobile Robot dalam Mengenali Gas
}

\author{
Rendyansyah*, Aditya P.P. Prasetyo dan Kemahyanto Exaudi \\ Jurusan Sistem Komputer, Fakultas Ilmu Komputer, Universitas Sriwijaya \\ "Corresponding author, e-mail: rendyansyah@ilkom.unsri.ac.id
}

\begin{abstract}
Abstrak - Aroma gas dapat dirasakan oleh indra penciuman manusia. Adanya aroma karena berasal dari sumber gas itu sendiri atau gas bocor melalui cela-cela seperti katup atau sambungan pipa. Aroma gas tertentu (gas dengan aroma yang menyengat) dapat mengganggu sistem saraf dan hidung manusia. Oleh karena itu perlu alat yang dapat meniru indra penciuman yaitu electronic nose (disingkat e-nose). E-nose merupakan kumpulan dari dua sensor gas atau lebih. Dalam situasi pencarian sumber aroma gas maka pada penelitian ini dikembangkan $e$-nose kedalam bentuk aplikasi olfactory mobile robot untuk deteksi dan identifikasi. Pada penelitian ini sistem dirancang untuk mengenali gas etanol, benzene dan thiner. Pengenalan pola sinyal dari e-nose menggunakan Support Vector Machine (SVM) yang sudah diprogram di dalam komputer. Secara ilustrasi aroma gas yang dideteksi oleh $e$-nose menghasilkan pola sinyal elektrik yang ditransfer via wireless ke komputer dan diproses untuk dikenali. Hasil percobaan menunjukkan bahwa olfactory mobile robot dapat diaplikasikan untuk mendeteksi dan mengidentifikasi jenis gas dengan akurasi yang baik, yaitu di atas $97 \%$ untuk pemilihan kernel $\gamma=100$ dan $\gamma=1000$.
\end{abstract}

\section{Kata Kunci : E-nose, Olfactory Mobile Robot, Support Vector Machine}

\begin{abstract}
The aroma of gas can be perceived by the human sense of smell. The presence of the scent comes from the gas source itself or the gas leaks through cracks such as valves or pipe connections. The smell of certain gases (gas with a stinging smell) can disrupt the human nervous system and nose. Hence, it is required a tool that can mimic the sense of smell which is called the electronic nose (abbreviated to enose). E-nose is a combination of two or more gas sensors. In a situation of searching the source of the gas scent, the e-nose was developed into a mobile robotic olfactory application for detection and identification process. In this study, the system was designed to recognize ethanol, benzene and thinner gases. The signal pattern recognition of e-nose uses the Support Vector Machine (SVM) programmed into the computer. Illustration of gas scent detected by e-nose produces a pattern of electrical signals that are wirelessly transferred to a computer and processed to be recognizable. The experimental results show that olfactory mobile robots can be applied to detect and identify types of gas with good accuracy, according to the value above $97 \%$ for kernel selection $\gamma=100$ and $\gamma=1000$.
\end{abstract}

Keywords : E-nose, Olfactory Mobile Robot, Support Vector Machine

\section{Pendahuluan}

Kebocoran gas akan menjadi masalah jika tidak ditangani secara langsung, misalnya pencemaran udara. Kebocoran gas dalam industri dapat terjadi akibat katup bocor, sambungan pipa atau korosi pada pipa. Pencarian aroma gas dapat dirasakan oleh indra penciuman manusia. Namun aroma gas berbahan kimia dapat menyebabkan iritasi atau gangguan pada sistem saraf pernapasan. Oleh karena itu, pada zaman modern ini banyak dikembangkan teknologi yang dapat meniru dalam pencarian aroma gas pada area kebocoran, yaitu electronic nose atau disingkat e-nose.

Dalam mempermudah situasi pencarian sumber aroma gas maka telah berkembang teknologi yang dapat membantu manusia yaitu salah satunya robot [1]. Robot sangat membantu dalam pekerjaan yang rumit seperti mengamati suatu objek yang dicurigai [2], dan pencarian target aroma gas [2, 3]. Oleh karena itu, penggunaan robot dapat mencegah resiko yang ditimbulkan akibat kelalaian dan kecelakaan, karena alasan utama untuk keselamatan kerja.

Pada penelitian ini mobile robot dirancang untuk bertindak sesuai keinginan pengguna yaitu menggunakan teknik guide. Teknik gerakan ini dikontrol secara manual, namun robot sudah dilengkapi dengan kamera dan $e$ nose yang terintegrasi menjadi olfactory mobile 
robot untuk tujuan identifikasi atau klasifikasi aroma. Adapun motivasinya didasarkan meniru cara orang dalam menginspeksi keadaan atau tempat yang diduga target kebocoran gas menggunakan mata dan hidung.

Adanya identifikasi jenis aroma gas karena terbentuk pola sinyal elektrik yang dihasilkan oleh sensor-sensor gas seperti yang pernah dilakukan oleh Frianto dan Rivai [4], dan Hasan dkk [5]. Mereka mengelompokkan pola sinyal tersebut untuk dilatih menggunakan metode Jaringan Syaraf Tiruan (JST) Bacpropagation dan Support Vector Machine (SVM), dan hasilnya diuji satu persatu untuk di-identifikasi. Metode JST dan SVM memiliki kesamaan untuk klasifikasi [4, 5], namun teknik SVM memiliki tingkat akurasi yang lebih baik. Sehingga pada penelitian ini digunakan metode SVM untuk klasifikasi aroma gas. Alasan menggunakan SVM karena proses pelatihan yang cepat dan akurasi yang baik untuk data yang bersifat non-linear. Adapun sistem e-nose, SVM dan mobile robot ini dapat mempermudah dalam pencarian dan identifikasi aroma gas.

\section{Tinjauan Pustaka}

\subsection{Electronic Nose}

Electronic nose atau disingkat e-nose merupakan penciuman elektronik yang dapat menirukan sistem indra penciuman manusia untuk mengenali suatu aroma. E-nose terdiri dari deretan beberapa sensor gas yang dirancang khusus dengan penerapan metode pengenalan pola atau sistem cerdas $[4,5,6]$. Adapun sensor gas yang sering digunakan umumnya tipe metal oxide semiconductor, salah satunya MQ. Penggunaan sensor perlu disesuaikan dengan jenis gas yang akan dideteksi. Gambar 1 menunjukkan contoh modul sensor gas tipe MQ. Adapun jenis sensor gas yang digunakan dalam penelitian ini yaitu tipe MQ 2, MQ 4 dan MQ 135 yang terdapat pada Tabel 1.

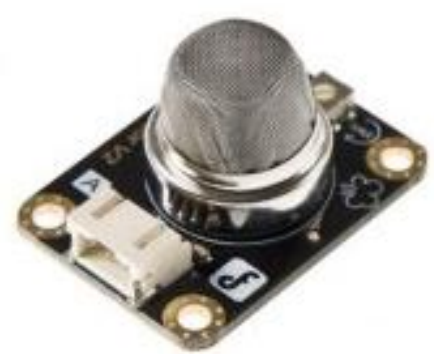

Gambar 1. Modul sensor gas MQ.

Tabel 1. Sensor gas MQ dan kegunaannya [7].

\begin{tabular}{|c|c|}
\hline $\begin{array}{c}\text { Sensor } \\
\text { gas MQ }\end{array}$ & Kegunaan \\
\hline MQ2 & $\begin{array}{c}\text { Deteksi gas mudah yang mudah terbakar, } \\
\text { contoh butane, LPG, Propane, dll } \\
\text { Deteksi Gas Natural, metana dan gas } \\
\text { mudah terbakar }\end{array}$ \\
MQ4 & $\begin{array}{c}\text { Air quality control (Benzena, } \mathrm{NH}_{3}, \\
\text { Alcohol, Smoke) }\end{array}$ \\
\hline
\end{tabular}

Berdasarkan kegunaan masing-masing sensor gas pada Tabel 1, maka dibangun deret sensor berupa $e$-nose. Adapun contoh konsep $e$ nose menurut rancangan yang diusulkan oleh Frianto dan Rivai [4] seperti pada Gambar 2.

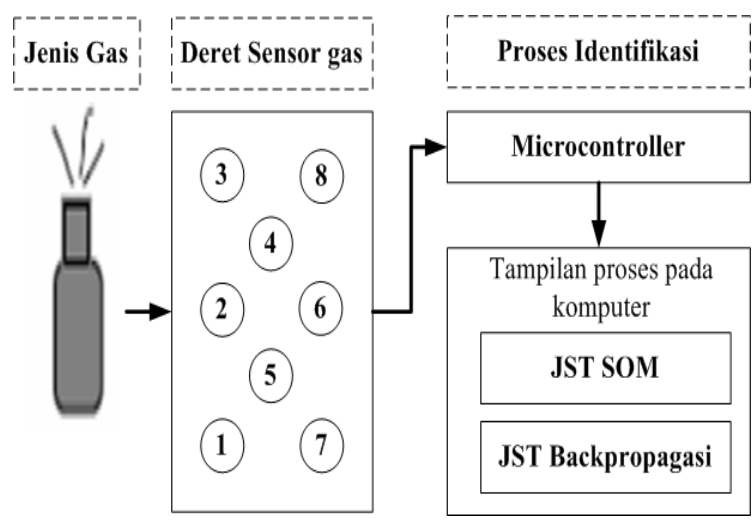

Gambar 2. Contoh konsep rancangan e-nose [4].

\subsection{Support Vector Machine}

Support vector machine disingkat SVM merupakan metode pembelajaran yang didasari pada teori statistik yang dikombinasikan dengan teori-teori belajar yang telah ada seperti kernel trick dan metode optimasi [8, 9]. SVM mampu mengklasifikasi data baik linear maupun nonlinear, dimana teknik ini selalu berusaha untuk mencari bidang pemisah atau hyperplane terbaik untuk memisahkan data sesuai kelas [8]. Salah satu contoh bidang pemisah hyperplane 
untuk kasus dua kelas ditunjukkan pada Gambar 3.

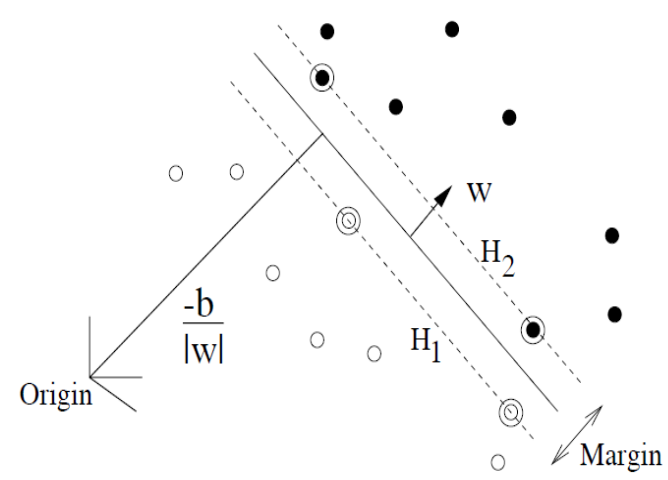

Gambar 3. Bidang pemisah hyperplane untuk kasus dua kelas [8].

Adapun untuk kasus klasifikasi lebih dari dua kelas dapat digunakan metode one vs other [10]. Gambar 4 memperlihatkan arsitektur SVM one vs other yang diimplementasikan pada $e$ nose.

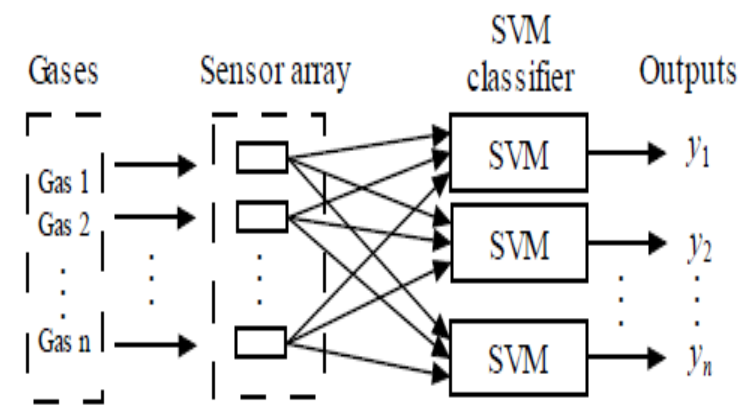

Gambar 4. Arsitektur SVM one vs other yang diimplementasikan pada e-nose [10].

Dari arsitektur pada Gambar 4 diketahui bahwa masing-masing SVM akan menentukan target yang diinginkan. Proses SVM yaitu menghitung Quadrating Programming bentuk ganda seperti pada Persamaan (1) sampai (3) untuk menghasilkan nilai support vector ( $\alpha \neq 0$ ).

$$
\begin{gathered}
\max _{a} \sum_{k=1}^{l} a_{k}-\frac{1}{2} \sum_{i=1}^{l} \sum_{j=1}^{l} a_{i} a_{j} y_{i} y_{j} K\left\langle x_{i}, x_{j}\right\rangle \\
\text { subject to: } \sum_{i=1}^{l} \alpha_{i} y_{i}=0 \\
0 \leq \alpha_{i} \leq C, i=1, \ldots, l
\end{gathered}
$$

Adapun solusi pada Persamaan (1) sampai (3) dapat diselesaikan dengan metode sequential SVM [11], sebagai berikut :

1. Inisialisasi nilai $\alpha_{i}=0$.

2. Menghitung matrik $D_{\mathrm{ij}}$.

$$
D_{i j}=y_{i} y_{j}\left(K\left\langle x_{i}, x_{j}\right\rangle+\lambda^{2}\right)
$$

untuk $i, j=1 \ldots l$, dan $l$ banyaknya data, dan paramater $\lambda$ yaitu konstanta.

3. Setiap pola yang akan diklasifikasi dihitung menggunakan Persamaan (5) sampai (7), dimana data pelatihan dari $i=1$ sampai $l$.

$$
\begin{aligned}
& E_{i}=\sum_{j=1}^{l} \alpha_{j} D_{i j} \\
& \delta \alpha_{i}=\min \left\{\max \left[\gamma\left(1-E_{i}\right),-\alpha_{i}\right], C-\alpha_{i}\right\} \\
& \alpha_{i}=\alpha_{i}+\delta \alpha_{i}
\end{aligned}
$$

Adapun $\gamma$ merupakan learning rate.

4. Jika selama proses pelatihan sudah terlihat konvergen maka proses tersebut dihentikan. Sebaliknya jika belum konvergen maka ulangi lagi proses pada Persamaan (5) sampai (7). Indikator tercapai konvergen apabila tingkat perubahan nilai $\delta \alpha_{i}$ kecil hampir mendekati nol.

Algoritma ini akan menghasilkan nilai lagrange $\alpha$ yang optimal untuk data yang akan di-cluster, dimana data input diubah ke fitur berdimensi tinggi menggunakan fungsi kernel, salah satunya kernel Radial Basis Function [10] seperti pada Persamaan (8). Untuk $\gamma$ merupakan parameter kernel dengan nilai yang ditentukan.

$$
K(\stackrel{\mathrm{r}}{x}, \stackrel{\mathrm{r}}{y})=\exp \left(-\gamma\|\stackrel{\mathrm{r}}{x}-\stackrel{\mathrm{r}}{y}\|^{2}\right)
$$

Dari hasil proses pelatihan tersebut maka dilakukan pengujian data untuk diklasifikasi. Adapun tahap pengujian sebagai berikut :

1. Menentukan jumlah kelas pada masingmasing SVM yaitu cluster +1 dan -1 .

2. Memetahkan data input $x$ ke dalam bentuk feature space menggunakan kernel $\mathrm{RBF}$ pada Persamaan (8).

3. Menghitung fungsi pengambilan keputusan terakhir [11], menggunakan Persamaan (9) dan (10).

$$
f(x)=\operatorname{sign}\left(\sum_{i \in S V} \alpha_{i} y_{i} K\left(x_{i}, x\right)+\alpha_{i} y_{i} \lambda^{2}\right)
$$




$$
\operatorname{sign}(k)=\left\{\begin{array}{ccc}
-1 & ; \quad k<0 \\
1 \quad ; & k \geq 0
\end{array}\right.
$$

Nilai SV merupakan banyaknya support vector, dan sign( $k$ ) untuk menentukan cluster.

\subsection{Olfactory Mobile Robot}

Mobile robot dengan fungsi mencari target kebocoran gas umumnya dikenal dengan istilah olfactory mobile robot. Mobile robot tersebut dilengkapi dengan berbagai jenis sensor gas atau e-nose dan bahkan ditambahkan juga kamera vision sebagai pelengkap [1, 12]. Adapun contoh olfactory mobile robot untuk deteksi gas seperti ditunjukkan pada Gambar 5. Tujuan olfactory mobile robot yaitu membantu sensor gas atau e-nose agar lebih leluasa dalam pencarian target aroma gas dan identifikasi, karena prinsipnya meniru prilaku makhluk hidup ketika sedang mencari sumber aroma.

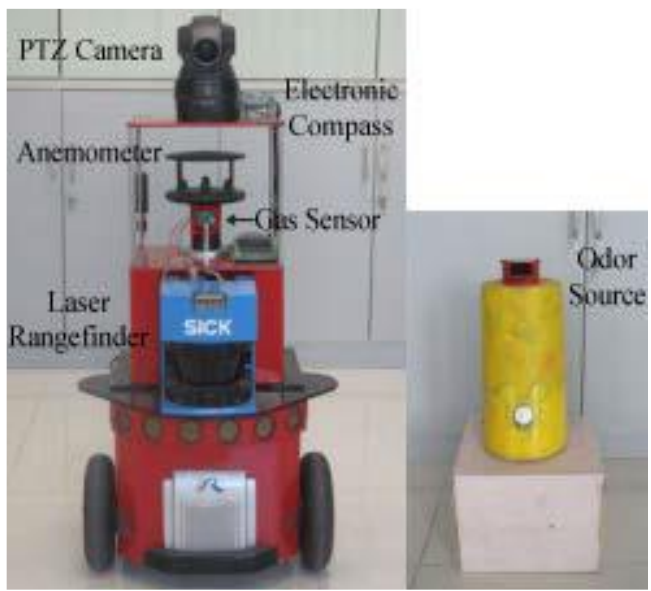

Gambar 5. Contoh fisik olfactory mobile robot pencari target aroma [12].

\section{Metoda}

\subsection{Perancangan $E$-Nose}

Pada penelian ini e-nose dirancang menggunakan tiga buah sensor gas metal oxide semiconductor tipe MQ. Sensor-sensor tersebut yaitu MQ2, MQ4 dan MQ135 yang memiliki kemampuan untuk sensing jenis gas yang berbeda, seperti yang terlihat pada Tabel 1 . Namun jenis gas yang akan diidentifikasi yaitu gas etanol, benzena dan thiner. Secara ilustrasi, sampel aroma gas tersebut didekatkan pada depan robot dengan bantuan pompa supaya diperoleh pola respon tegangan masing-masing sensor.

Respon tersebut akan dikonversi oleh mikrokontroler ATMega menjadi data digital supaya dapat ditrasfer ke komputer via transceiver. Di dalam komputer, pola data tersebut diproses untuk dikenali menggunakan metode Support Vector Machine. Untuk lebih jelas, Gambar 6 menunjukkan suatu konsep alur dari skematik hardware pada e-nose.
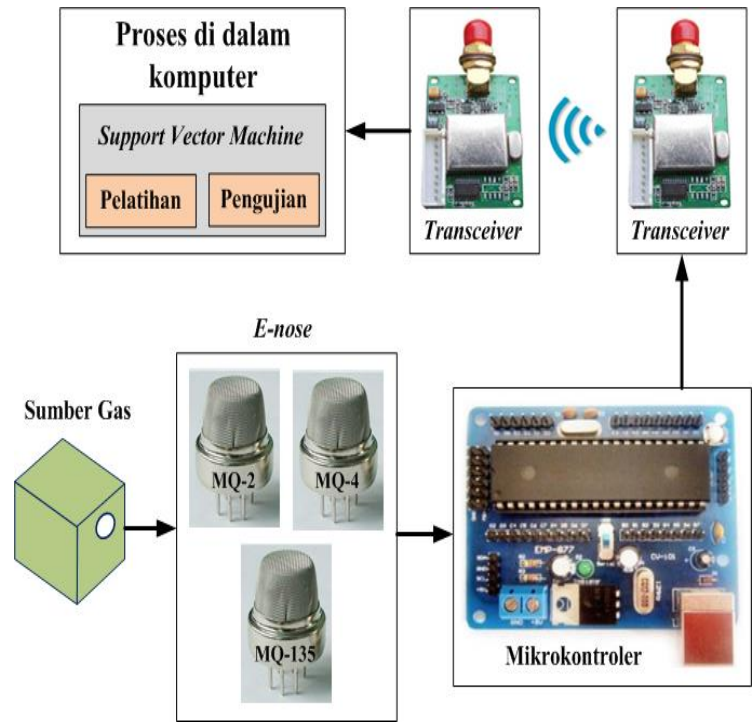

Gambar 6. Alur dari skematik hardware pada $e$ nose.

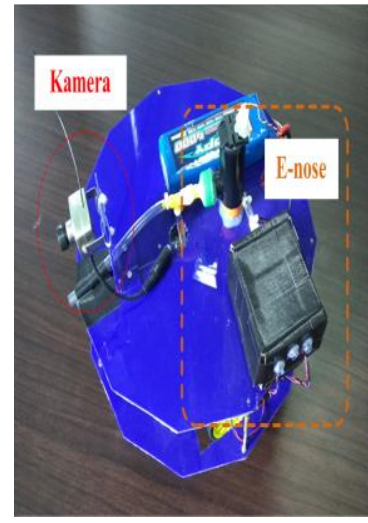

(a)

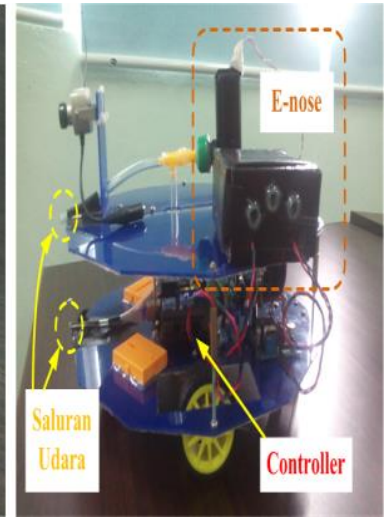

(b)
Gambar 7. Olfactory mobile robot, (a) tampak atas, dan (b) tampak samping. 


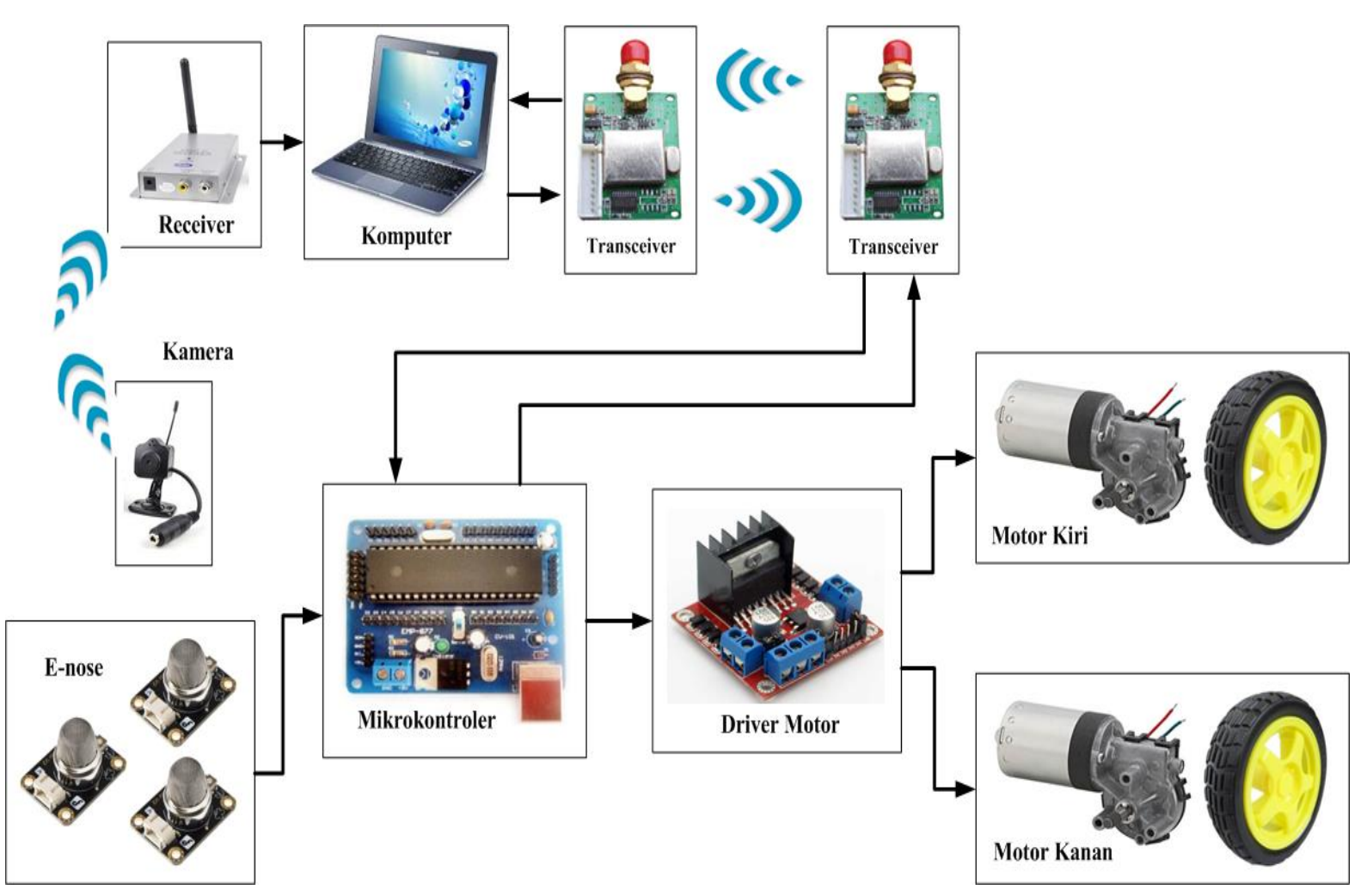

Gambar 8. Skematik hardware pada olfactory mobile robot.

\subsection{Perancangan Olfactory Mobile Robot}

Pada tahap ini dilakukan pembuatan mobile robot yang terintegrasi dengan e-nose. Mobile robot juga dilengkapi kamera wireless sebagai navigator guide secara manual berbasis komputer. Adapun mobile robot ini dirancang dengan bentuk segi delapan. Gambar 7 menunjukkan bentuk fisik olfactory mobile robot. Adapun skematik hardware pada

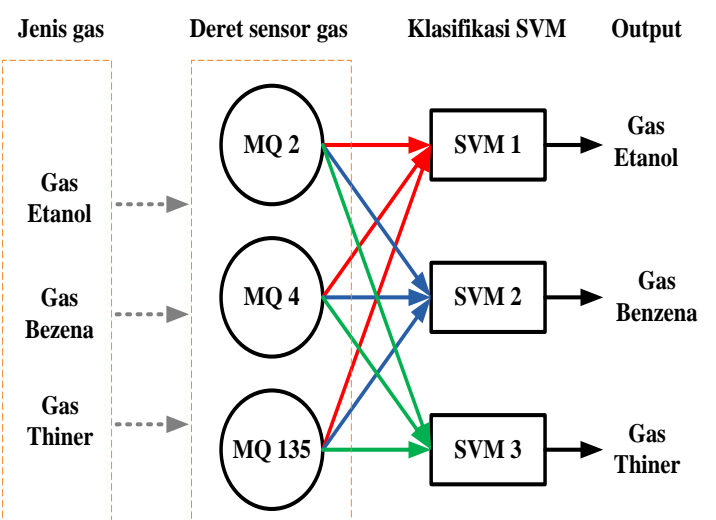

Gambar 9. Arsitektur SVM konsep one vs other. olfactory mobile robot ditunjukkan pada Gambar 8. Berdasarkan ilustrasi skematik pada Gambar 8, ditunjukkan bahwa robot memiliki satu kontroler. Kontroler tersebut digunakan untuk memproses data dari sensor gas (e-nose) yang ditransfer ke komputer dan juga untuk mengontrol gerak robot berdasarkan masukkan guide manual dari komputer. Guide manual merupakan kontrol yang diberikan oleh pengguna melalui monitoring berbasis komputer dengan bantuan kamera sebagai mata pengguna.

\subsection{Perancangan algoritma Support Vector Machine}

Pada tahap ini dilakukan perancangan algoritma SVM. SVM ini akan dilatih dan diuji didalam komputer. Data pelatihan SVM yaitu pola dari keluaran sensor e-nose saat deteksi gas. Adapun data pengujian yaitu data pola secara random atau gas yang diuji secara langsung. Dalam pelatihan dan pengujian perlu dirancang juga arsitektur SVM. Arsitektur SVM dibangun berdasarkan konsep one vs other seperti pada Gambar 9. 


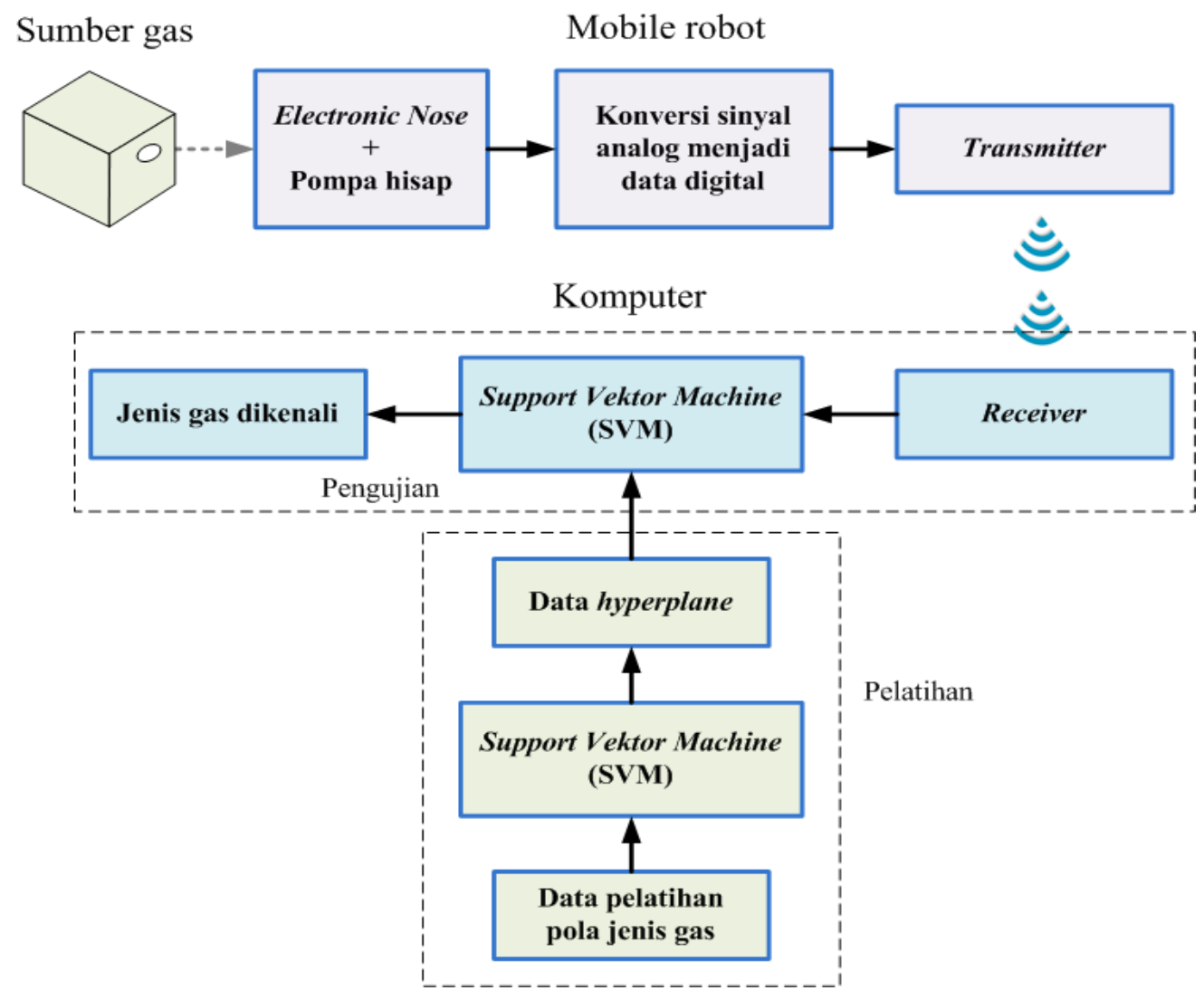

Gambar 10. Implementasi SVM pada olfactory mobile robot.

Berdasarkan arsitektur pada Gambar 9, ditunjukkan bahwa SVM pertama berfungsi untuk mengenali gas etanol terhadap gas lainnya, begitu juga untuk SVM kedua maupun ketiga. Dengan kata lain, SVM ini umumnya hanya untuk meng-cluster dua kelas, yaitu +1 dan -1. Modul SVM satu sampai tiga ini memiliki data hyperplane yang berbeda. Adapun alur implementasi SVM pada olfactory mobile robot dapat dilihat pada Gambar 10.

\section{Hasil dan Pembahasan}

\subsection{Pengujian kontrol manual untuk gerak robot}

Pada percobaan ini, mobile robot dijalankan dalam arena skala laboratorium yang berukuran $240 \mathrm{~cm} \times 360 \mathrm{~cm}$. Arena ini merupakan ilustrasi saat terjadi kebocoran gas. Adapun target bocor berupa objek kotak yang telah dirancang khusus dan bisa memompakan aroma gas. Aroma gas tersebut yaitu etanol, benzene dan thiner, yang pengujiannya dilakukan secara bergantian.
Mobile robot ini diuji untuk menuju target yang dikendalikan secara manual seperti pada Gambar 11. Kendali manual dapat dilakukan dengan meng-click button ("maju", "mundur", "kiri" dan "kanan") pada tampilan visual, atau dengan menekan keyboard tanda panah. Adapun tampilan monitoring berbasis visual untuk menggerakan mobile robot seperti pada Gambar 12.

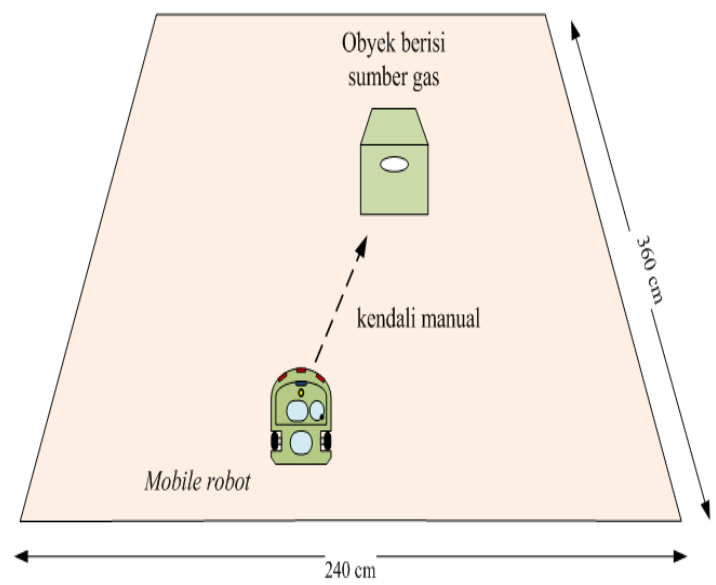

Gambar 11. Arena percobaan untuk robot. 


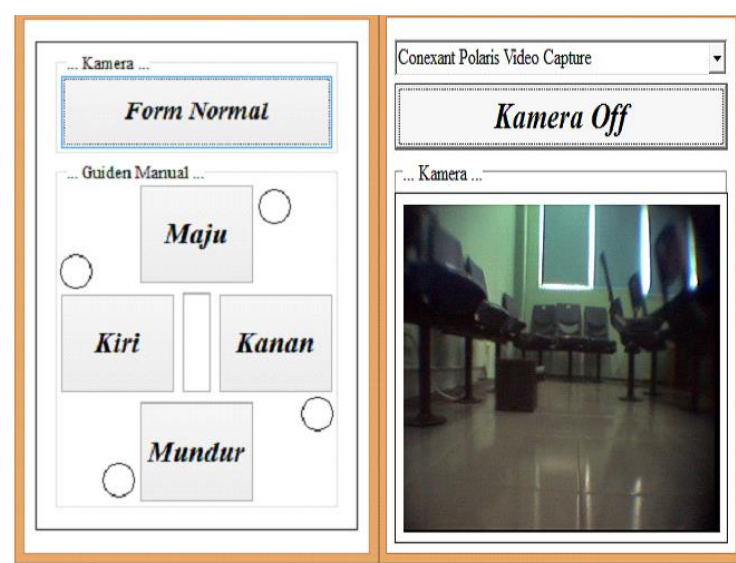

Gambar 12. Tampilan monitoring untuk kontrol manual.

Cara pengujian ini dilakukan tanpa ada halangan antara receiver pada robot dengan transmitter pada komputer. Adapun hasil pengujian kendali manual perintah gerak untuk mobile robot ditunjukan pada Tabel 2. Pada pengujian ini dimulai pada jarak $2 \mathrm{~m}$, berikutnya $5 \mathrm{~m}, 10 \mathrm{~m}, 20 \mathrm{~m}$ dan $30 \mathrm{~m}$ antar pengguna dengan robot. Pada jarak $30 \mathrm{~m}$, robot masih mampu menerima respon perintah gerak dari komputer, dimana robot tersebut masih terlihat oleh pengguna.

Tabel 2. Hasil pengujian perintah gerak berbasis komputer.

\begin{tabular}{|l|l|l|}
\hline No & $\begin{array}{l}\text { Perintah Gerak } \\
\text { Robot }\end{array}$ & \multicolumn{1}{|c|}{$\begin{array}{c}\text { Respon Hasil } \\
\text { Pergerakan }\end{array}$} \\
\hline 1 & $\begin{array}{l}\text { Tombol maju } \\
(\text { logic }=1)\end{array}$ & $\begin{array}{l}\text { Robot bergerak maju } \\
\text { Tombol kiri } \\
(\text { logic }=2)\end{array}$ \\
3 & $\begin{array}{l}\text { Tombol kanan } \\
(\text { logic }=3) \\
\text { Robot bergerak ke } \\
\text { kiri } \\
\text { Rombol mundur } \\
(\text { logic }=4)\end{array}$ & $\begin{array}{l}\text { kanan bergerak ke } \\
\text { Robot bergerak } \\
\text { mundur }\end{array}$ \\
\hline
\end{tabular}

Ketika robot sudah mendekat dengan target maka sensor $e$-nose diaktifkan, dan informasi ditrasfer ke komputer. Gambar 13 menunjukkan posisi robot ketika sudah mendekati target sumber gas. Jika robot belum memberikan informasi hasil deteksi dan identifikasi maka robot dikendalikan untuk bergerak mengitari objek selama satu putaran. Sementara Gambar 14 menunjukkan respon sensor gas ketika diujikan dengan gas metanol.

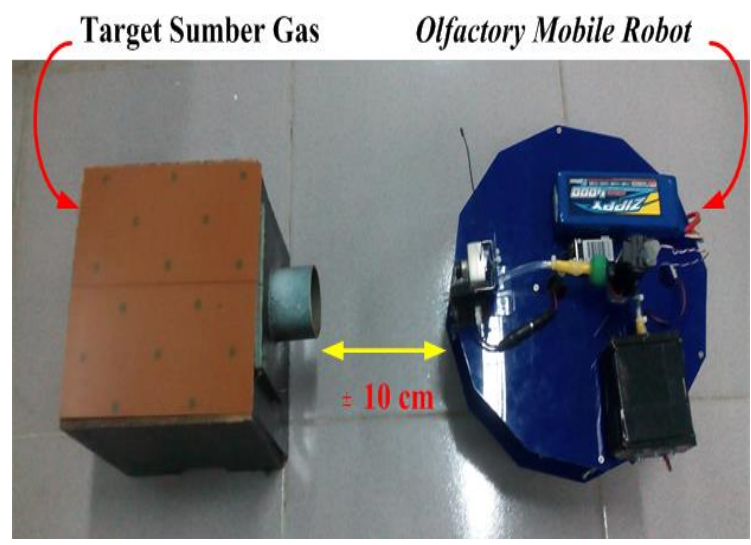

Gambar 13. Posisi robot ketika sudah mendekati target sumber gas.

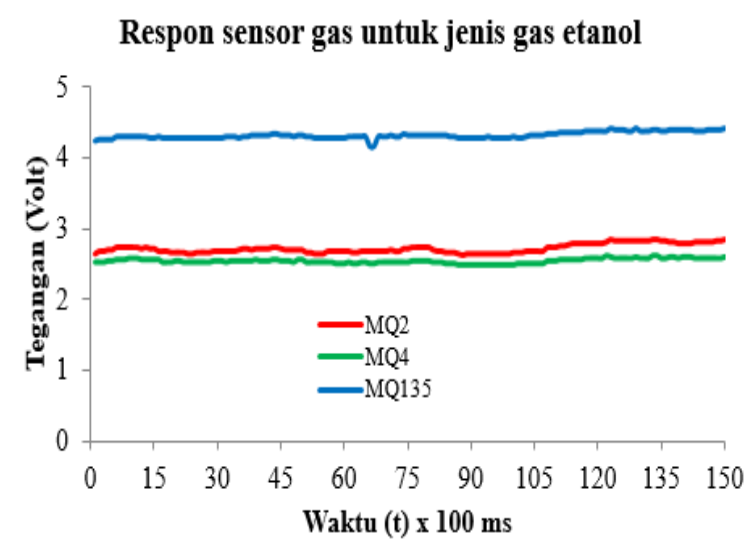

Gambar 14. Respon sensor gas ketika diujikan dengan jenis gas etanol.

\subsection{Pengujian olfactory mobile robot untuk identifikasi gas}

Adapun pengujian ini seperti ilustrasi yang ditunjukkan pada Gambar 13. Pertama kali dilakukan uji coba untuk mengetahui respon sinyal dari sensor-sensor gas. Pengujian tersebut dilakukan sebanyak dua kali untuk spesifik gas etanol, benzena dan thiner pada posisi jarak robot dengan target gas yaitu $3 \mathrm{~cm}$, $6 \mathrm{~cm}, 9 \mathrm{~cm}, 12 \mathrm{~cm}$ dan $15 \mathrm{~cm}$. Masing-masing jenis gas tidak diberi pengaruh terhadap gas lain dengan kata lain kondisi udara di dalam ruangan bebas aroma. Pengujian ini memerlukan pompa untuk mengilustrasikan adanya kebocoran dengan debit aliran yang tetap yaitu $\pm 2400 \mathrm{ml}$ per menit.

Dari percobaan ini diperoleh respon masingmasing sensor gas dan diambil polanya. Adapun respon sensor-sensor gas ketika diuji pada satu sampel jarak $\pm 6 \mathrm{~cm}$ untuk tiap jenis gas seperti ditunjukkan pada Gambar 14, 
Gambar 15 dan Gambar 16. Berdasarkan Gambar 14, Gambar 15 dan Gambar 16, data tersebut diambil ketika keluaran respon sensorsensor gas dalam keadaan stabil dan tidak ada perubahan secara signifikan. Sehingga dapat dikatakan sensor mampu mendeteksi dan membaca pola dari tiga jenis gas tersebut.

\section{Respon sensor gas untuk jenis gas benzena}

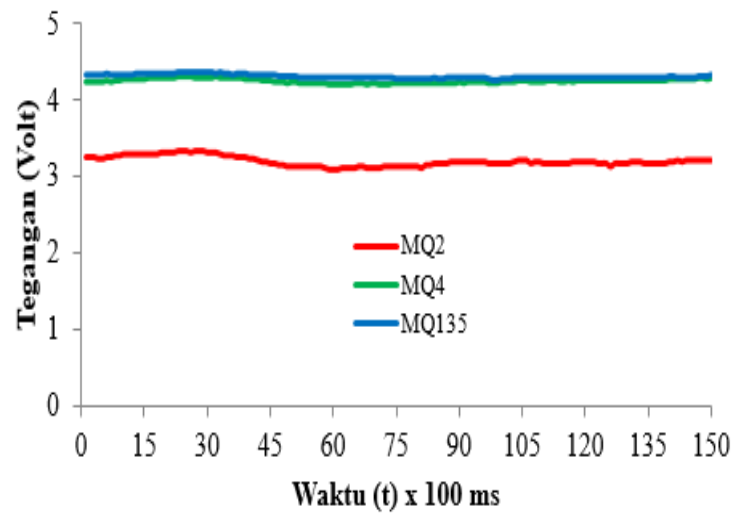

Gambar 15. Respon sensor gas ketika diujikan dengan jenis gas benzena.

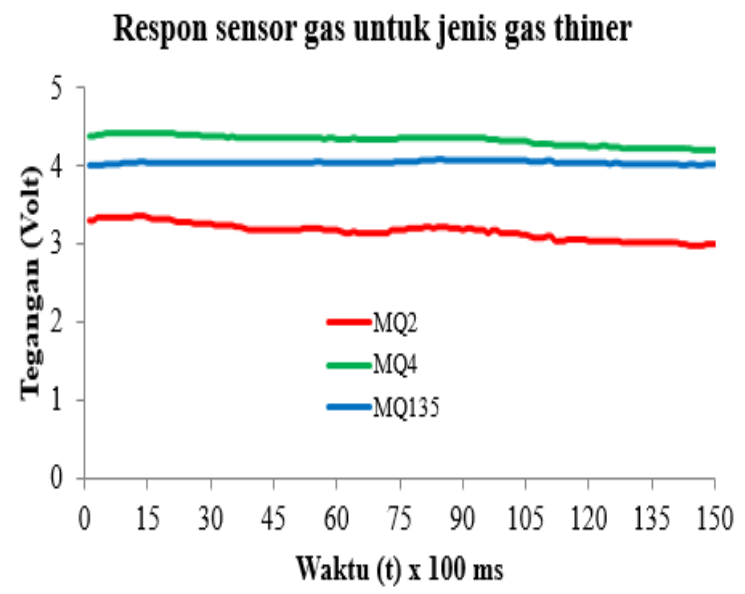

Gambar 16. Respon sensor gas ketika diujikan dengan jenis gas thiner.

Dari pengukuran tersebut diperoleh pola tegangan dari masing-masing sensor, dan pola tersebut dilatih kemudian diuji. Adapun tanggapan respon e-nose sebagai data pola untuk gas etanol, benzene dan thiner. Adapun pola tersebut diambil nilai rata-rata dari keseluruhan data percobaan pada setiap jenis sampel gas untuk masing-masing jarak yang telah ditentukan seperti ditunjukkan pada Tabel 3, Tabel 4 dan Tabel 5.
Tabel 3. Pola respon e-nose saat deteksi gas etanol.

\begin{tabular}{|c|c|c|c|}
\hline \multirow{2}{*}{$\begin{array}{c}\text { Jarak } \\
(\mathbf{c m})\end{array}$} & \multicolumn{3}{|c|}{ Tegangan (Volt) } \\
\cline { 2 - 4 } & $\begin{array}{c}\text { Sensor } \\
\text { MQ2 }\end{array}$ & $\begin{array}{c}\text { Sensor } \\
\text { MQ4 }\end{array}$ & $\begin{array}{c}\text { Sensor } \\
\text { MQ135 }\end{array}$ \\
\hline 3 & 3.68 & 3.24 & 4.66 \\
6 & 2.72 & 2.54 & 4.34 \\
9 & 2.4 & 2.33 & 4.10 \\
12 & 2.16 & 2.22 & 3.82 \\
15 & 1.93 & 1.99 & 3.15 \\
\hline
\end{tabular}

Tabel 4. Pola respon e-nose saat deteksi gas benzena.

\begin{tabular}{|c|c|c|c|}
\hline \multirow{2}{*}{$\begin{array}{c}\text { Jarak } \\
(\mathbf{c m})\end{array}$} & \multicolumn{3}{|c|}{ Tegangan (Volt) } \\
\cline { 2 - 4 } & $\begin{array}{c}\text { Sensor } \\
\text { MQ2 }\end{array}$ & $\begin{array}{c}\text { Sensor } \\
\text { MQ4 }\end{array}$ & $\begin{array}{c}\text { Sensor } \\
\text { MQ135 }\end{array}$ \\
\hline 3 & 3.60 & 4.47 & 4.64 \\
6 & 3.21 & 4.25 & 4.31 \\
9 & 2.48 & 3.34 & 3.77 \\
12 & 2.30 & 3.11 & 3.35 \\
15 & 2.28 & 2.95 & 3.09 \\
\hline
\end{tabular}

Tabel 5. Pola respon e-nose saat deteksi gas thiner.

\begin{tabular}{|c|c|c|c|}
\hline \multirow{2}{*}{$\begin{array}{c}\text { Jarak } \\
(\mathbf{c m})\end{array}$} & \multicolumn{3}{|c|}{ Tegangan (Volt) } \\
\cline { 2 - 4 } & $\begin{array}{c}\text { Sensor } \\
\text { MQ2 }\end{array}$ & $\begin{array}{c}\text { Sensor } \\
\text { MQ4 }\end{array}$ & $\begin{array}{c}\text { Sensor } \\
\text { MQ135 }\end{array}$ \\
\hline 3 & 3.75 & 4.67 & 4.36 \\
6 & 3.17 & 4.35 & 4.05 \\
9 & 2.99 & 4.09 & 3.62 \\
12 & 2.49 & 3.31 & 3.06 \\
15 & 2.37 & 3.20 & 2.68 \\
\hline
\end{tabular}

Untuk memudahkan proses pelatihan, data pola pada Tabel 3, Tabel 4 dan Tabel 5 dinormalisasi yaitu respon sinyal keluaran dari setiap sensor dibagi dengan nilai sepuluh. Adapun bentuk pola untuk jenis gas etanol, benzene dan thiner yang dinormalisasi masingmasing seperti yang ditunjukan pada Gambar 17, Gambar 18 dan Gambar 19.

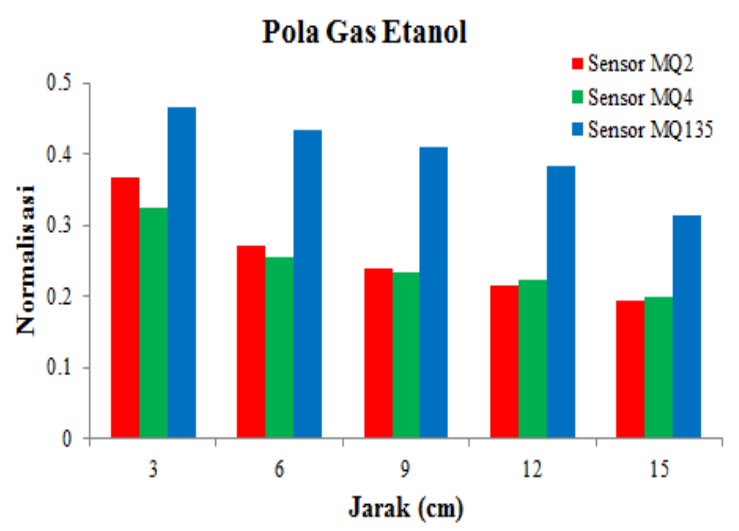

Gambar 17. Pola gas etanol. 


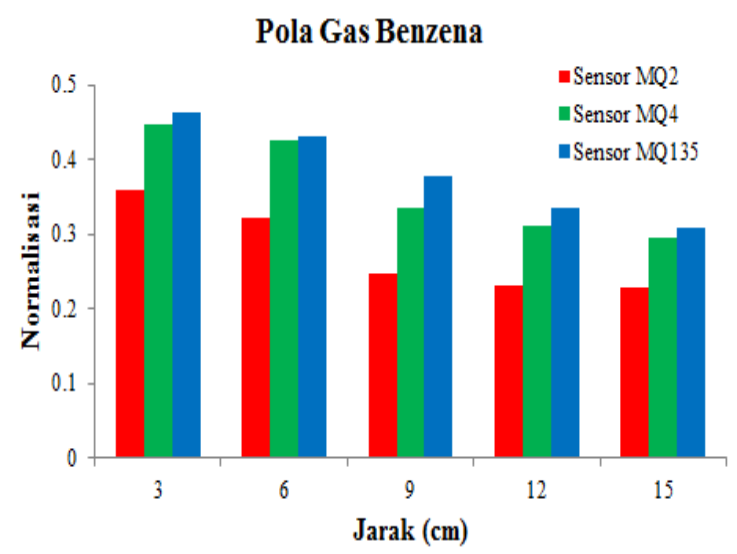

Gambar 18. Pola gas benzena.

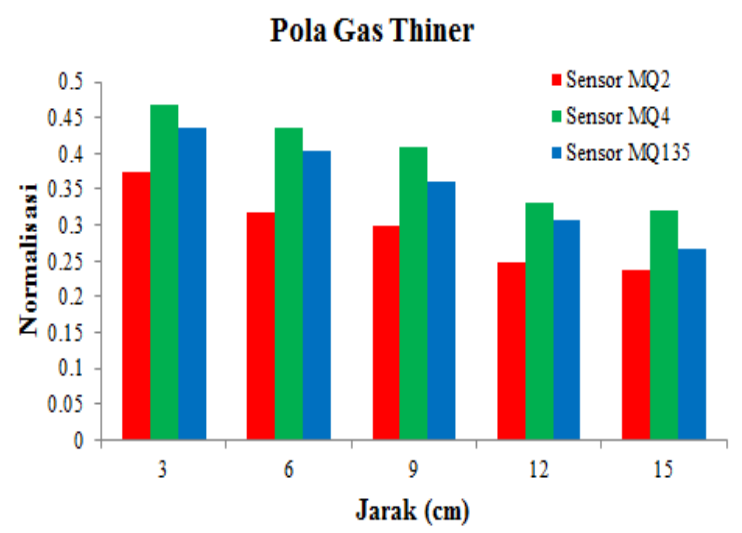

Gambar 19. Pola gas thiner.

Berdasarkan arsitektur pada Gambar 9, untuk kelas pertama yaitu kelas gas etanol terhadap kelas gas lainnya. Kelas dua yaitu kelas gas benzena terhadap kelas gas lainnya, dan kelas tiga yaitu kelas gas thiner terhadap gas lainnya. Pada saat gas etanol tidak dikenali maka SVM membandingkan dengan kelas dua maupun kelas tiga, dan begitu juga untuk kelas pada gas benzene dan thiner. Namun jika data tersebut tidak termasuk di dalam kelas satu sampai tiga maka indikatornya "Bukan Gas Yang Dikenali”.

Pada program SVM yang telah dirancang terdapat parameter $C$ dan kernel $\gamma$ yang digunakan saat proses pelatihan dan pengujian. Oleh karena itu perlu ditentukan nilai parameter yang tepat sehingga diperoleh tingkat akurasi dari keberhasilan metode SVM untuk klasifikasi. Karena belum diketahui nilai parameter tersebut maka untuk menentukannya terasa sulit, sehingga pada pengujian ini parameter kernel $\gamma$ ditentukan nilai yang bervariasi dalam menemukan hyperplane yang baik. Adapun untuk nilai parameter $C=10$ bersifat tetap. Hasil pengujian identifikasi untuk tiga jenis gas menggunakan SVM one vs other ditunjukan pada Tabel 6.

Tabel 6. Pengujian identifikasi untuk tiga jenis gas menggunakan SVM one vs other.

\begin{tabular}{|c|c|c|c|c|c|}
\hline \multirow{2}{*}{$\begin{array}{c}\text { Jarak } \\
(\mathrm{cm})\end{array}$} & \multirow{2}{*}{$\begin{array}{c}\text { Parameter } \\
\text { Kernel ( } \\
\gamma)\end{array}$} & \multirow{2}{*}{$\begin{array}{c}\text { Jumlah } \\
\text { sampel } \\
\text { data }\end{array}$} & \multicolumn{3}{|c|}{$\begin{array}{c}\text { Akurasi Pengenalan Pola } \\
(\%)\end{array}$} \\
\hline & & & Etanol & Bensin & Tiner \\
\hline \multirow{5}{*}{3} & 1 & 150 & 68 & 0 & 0 \\
\hline & 10 & 150 & 100 & 0 & 100 \\
\hline & 100 & 150 & 100 & 90.67 & 100 \\
\hline & 1000 & 150 & 91.33 & 90 & 100 \\
\hline & 10000 & 150 & 23.33 & 42 & 90.67 \\
\hline \multirow{5}{*}{6} & 1 & 150 & 100 & 0 & 0 \\
\hline & 10 & 150 & 100 & 0 & 100 \\
\hline & 100 & 150 & 100 & 100 & 100 \\
\hline & 1000 & 150 & 100 & 100 & 100 \\
\hline & 10000 & 150 & 83.33 & 90 & 57.33 \\
\hline \multirow{5}{*}{9} & 1 & 150 & 100 & 0 & 0 \\
\hline & 10 & 150 & 100 & 0 & 100 \\
\hline & 100 & 150 & 100 & 98 & 100 \\
\hline & 1000 & 150 & 100 & 98 & 100 \\
\hline & 10000 & 150 & 80 & 72.67 & 60 \\
\hline \multirow{5}{*}{12} & 1 & 150 & 100 & 0 & 0 \\
\hline & 10 & 150 & 100 & 0 & 100 \\
\hline & 100 & 150 & 100 & 100 & 100 \\
\hline & 1000 & 150 & 100 & 98.67 & 100 \\
\hline & 10000 & 150 & 40 & 19.33 & 60 \\
\hline \multirow{5}{*}{15} & 1 & 150 & 100 & 0 & 0 \\
\hline & 10 & 150 & 100 & 0 & 99.33 \\
\hline & 100 & 150 & 100 & 100 & 98.67 \\
\hline & 1000 & 150 & 96.67 & 91.33 & 98.67 \\
\hline & 10000 & 150 & 37.33 & 28.67 & 33.33 \\
\hline
\end{tabular}

Berdasarkan hasil pengujian pada Tabel 6 , menunjukkan bahwa teknik SVM mampu mengenali tiga jenis gas dan telah diuji dari jarak $3 \mathrm{~cm}$ sampai $15 \mathrm{~cm}$ antar robot dengan target sumber gas. Adapun hasil terbaiknya mencapai akurasi rata-rata $99.15 \%$ yaitu dengan menentukan nilai parameter kernel $\gamma=100$. Begitu juga untuk parameter kernel $\gamma=1000$ dengan akurasi rata-rata $97.64 \%$. Oleh karena itu kernel $\gamma=100$ dan $\gamma=1000$ digunakan untuk proses pelatihan dan pengujian di dalam program SVM. Kesalahan yang terjadi dalam pengenalan pola karena kemungkinan masih terdapat sisa gas sebelumnya yang masih menempel di dalam membran sensor.

\section{Kesimpulan}

Pada penelitian ini telah dikembangkan mobile robot yang terintegrasi dengan e-nose menjadi olfactory mobile robot untuk mendeteksi dan mengenali gas. Olfactory mobile robot di-guide secara manual berbasis monitoring komputer untuk menuju target sumber gas. Jenis gas dideteksi oleh e-nose 
kemudian ditransfer ke komputer via wireless kemudian data diolah di dalam komputer untuk diklasifikasi menggunakan metode SVM. Berdasarkan percobaan yang telah dilakukan, olfactory mobile robot mampu mendeteksi dan mengenali gas etanol, benzena dan thiner dengan tingkat akurasi rata-rata di atas $97 \%$ untuk pemilihan nilai kernel 100 dan 1000 . Adapun pengembangan penelitian selanjutnya dapat di-embedd kontrol gerak otomatis berbasis kontrol cerdas atau komputer vision.

\section{Ucapan Terima Kasih}

Terima kasih disampaikan kepada Lembaga Penelitian dan Pengabdian Masyarakat (LPPM) Universitas Sriwijaya yang telah mendanai penelitian ini.

\section{Daftar Pustaka}

[1] Ishida, H., Ushiku, T., Toyama, S., Taniguchi, H. dan Moriizum, T., Mobile Robot Path Planning Using Vision and Olfaction to Search for a Gas Source, Sensors, Hal. 1112-115, (2005).

[2] Loutfi, A., Broxvall, M., Coradeschi, S., and Karlsson, L., Object Recognition: a New Application for Smelling Robots. Robotics and Autonomous Systems. Vol. 52, Issue 4. Hal. 272-289, (2005).

[3] Loutfi, A., Coradeschi, S., Karlsson, L., and Broxvall, M., Putting Olfaction into Action: Using an Electronic Nose on a Multi-Sensing Mobile robot, IEEE/RSJ International Conference on. Vol. 1. Hal 337-342, (2004).

[4] Frianto, H.T. dan Rivai, M, Implementasi Jaringan Syaraf Tiruan Backpropagation dan Self Organizing Map Menggunakan Sensor gas Semikonduktor Sebagai Identifikasi Jenis Gas, Seminar Nasional Informatika. Hal. 219-228, (2008).

[5] Hasan, N., Ejaz, N., Ejaz, W., and Kim, H.S., Malicious Odor Item Identification using an Electronic Nose based on Support Vector Machine Classification, The 1st IEEE Global Conference on Consumer Electronics. Hal. 399-400, (2012).
[6] Rabersyah, D., Firdaus dan Derisma, Identifikasi Jenis Bubuk Kopi Menggunakan Electronic Nose Dengan Metode Pembelajaran Bacpropagation, Jurnal Nasional Teknik Elektro, Vol. 5, No. 3, Hal. 332-338, (2016).

[7] Rivai, M., Tasripan dan Rois, M., Klasifikasi Aroma Tembakau Menggunakan Deret Sensor Tin-Oxide dan Neural Network, JAVA Journal of Electrical and Electronics Engineering, Vol. 9, No. 2, Hal. 95-100, (2011).

[8] Byun, H., and Lee S.W, A Survey on Pattern Recognition Applications of Support Vector Machines, International Journal of Pattern Recognition and Artificial Intelligence. Vol. 17, No. 3. Hal. 459-486, (2003).

[9] Jiang, P., Zeng, M., Meng, Q., Li, F., dan $\mathrm{Li}, \mathrm{Y}$, A Novel Object Recognition Method for Mobile robot Localizing a Single Odor/Gas Source in Complex Environments. Robotics, Automation and Mechatronics, IEEE Conference. Hal. 15, (2008)

[10] Wang, X., Zhang, H.R, dan Zhang, C.J, Signal Recognition of Electronic Nose Based on Support Vector Machines, Proceeding of the Fourth International Conference on Machine Learning and Cybernetics. Hal. 3394-3398, (2005).

[11] Vijayakumar, S dan Wu, S., Sequential Support Vector Classifiers and Regression, Proceeding International Conference on Soft Computing (SOCO'99). Hal. 610-619, (1999).

[12] Jiang, P., Hong, X., dan Ge, A., Mobile Robot Gas Source Localization Based on Behavior Strategies. Proceedings of the 33rd Chinese Control Conference. Hal. 8304-8308, (2014).

\section{Biodata Penulis}

Rendyansyah, Pendidikan terakhir s2- Teknik Elektro ITS lulus tahun 2015. Penulis sebagai tenaga pengajar jurusan Sistem Komputer Universitas Sriwijaya tahun 2016 sampai sekarang. Adapun bidang riset yang ditekuni yaitu Sistem Embedded dan Robotika. 
Aditya. P. P. Prasetyo, Pendidikan terakhir s2Teknik Elektro ITS lulus tahun 2015. Penulis sebagai tenaga pengajar jurusan Sistem Komputer Universitas Sriwijaya tahun 2016 sampai sekarang. Adapun bidang riset yang ditekuni yaitu Sistem Embedded dan Robotika.
Kemahyanto Exaudi, Pendidikan terakhir s2Teknik Elektro ITS lulus tahun 2015. Penulis sebagai tenaga pengajar jurusan Sistem Komputer Universitas Sriwijaya tahun 2016 sampai sekarang. Adapun bidang riset yang ditekuni yaitu Sistem Embedded dan Robotika. 